alert, her smile was so bright, and her eyes so keen. Left the only two of our family, we spent so many years together in pleasant companionship. Marion passed from this life in January, 1942, at the age of ninety-four. Now, the visits of dear friends must keep me company.

As I sit at the wide west window of my apartment with the sun pouring in its warmth and golden color, making beautiful the days I walk the sunset trail, my thoughts flit back to all the many scenes and activities that have been crowded into my ninety-two years. And they have been so many! In this story, I have included, for the most part, only those that center about the early Iowa home. "Nearly an hundred years! So they not seem long?" you ask. No, they seem short.

The prevailing influences in my life have been those bequeathed me by my pioneer parents: energy, thrift, perseverance, and upright living. Seeming to prove the accusation that all old people harp upon "the good old days," I close with the opinion that no modern slant on life, based on loose and easy living, can equal the spirit I saw demonstrated daily in my pioneer family.

\title{
CATTLE TWENTY-SIX DAYS ON ROAD
}

William H. Gurney sold 106 head of cattle, fed by Pierson \& Clapp, near Burlington, Iowa. These are native breed, pretty well fed, have come into market, considering the distance in fine condition; twenty-six days from home; on foot 120 miles, then by the Rock Island road to Chicago, Michigan Central to Detroit, Great Western through Canada to the suspension bridge, and by Central and Hudson here at about $\$ 20$ per head expense. They are fair average medium quality, and will sell for about $\$ 68$ per head or $9 \frac{1}{2}$ to $10 \mathrm{c}$ per pound. -New York Tribune, April 28, 1854. 
Copyright of Annals of Iowa is the property of State of Iowa, by \& through the State Historical Society of Iowa and its content may not be copied or emailed to multiple sites or posted to a listserv without the copyright holder's express written permission. However, users may print, download, or email articles for individual use. 